\title{
REVIEW OF ACTUAL METHODS AND TECHNOLOGIES OF WATER TREATMENT IN FIELD CONDITIONS (literature review)
}

\author{
A.V. Kuzminichuk, I.M. Astrelin \\ National Technical University of Ukraine "Igor Sikorsky Kyiv Polytechnic Institute", Kyiv \\ kuzminchuk.a@gmail.com
}

The review is devoted to the problem of water purification in the field. Given list and description of methods of drinking water purification in the field, specifically the disinfection, mechanical filtration, desalination, adsorption, and membrane separation processes. Existing in Ukraine and worldwide agents (tablets, solutions) and devices (UV emitters) for water disinfection, individual filtration devices, and group drinking water treatment plants. A critical analysis of the advantages and disadvantages of all considered technologies has been carried out.

Key words: drinking water, field conditions, microfiltration, chlorine tablets.

Drinking water is water that is suitable for human consumption and will bring the minimum harm to the human organism. The issue of drinking water preparation in the field is one of the most urgent when planning people location in places or situations where access to stationary sources of centralized water supply is impossible (hostilities, emergency situations, hiking trips).

According to the long duration of the situation in the East of Ukraine, the problem of water preparation in the field still has no unified solution, although there is a positive dynamics.

The main ways of ensuring the personnel of the military units, NGOs, emergency services and the civilians of drinking water in the field are:

- delivery of drinking bottled water;

- the use of conditionally safe water without treatment;

- consumption of water treated with disinfectants and/or boiling;

- use of group and individual water treatment (rarely).

\section{Disinfection processes}

If there are no sources of quality drinking water, disinfection is the easiest and cheapest option for the organization of safe water supply. The disinfection processes are based mainly on the oxidation of microbiological and partly organic contaminants.

In the field, due to the simplicity of implementation, mainly chemical and photocatalytic methods of drinking water disinfection are used.

\section{Chemical methods of water disinfection}

According to these methods of water treatment, reagents based on compounds of chlorine, iodine, hydrogen peroxide, silver salts and their compositions have widespread use. There are several types of commodity forms of disinfectants: pills, liquids, liquid and loose products.

\section{Chlorine-based products}

The main component of tableted and granulated chlorine products used for water treatment in the field is a sodium salt of the dichlorocyanuric acid, which contains about $70 \%$ of active chlorine. This acid and its sodium salts differ from other compounds of chlorine with high bactericidal activity, chemical resistance, and comparatively low toxicity. The mechanism of action of this reagent is based on the fact that the interaction of sodium dichloroisocyanurate with water forms a hypochlorite acid, which is stable at $\mathrm{pH}=6.2$, and this acidity is supported by acids, which are also part of the appropriate agents. Isocyanuric acid acts as a stabilizer and slows the dissolution of the reagent so that the active chlorine is released gradually, that is, at the beginning of the action only 
$50 \%$ are free (in the form of $\mathrm{HClO}$ and $\mathrm{ClO}^{-}$), and the other $50 \%$ are bound. This is due to the prolonged disinfectant action of chlorocianyrates and their resistance to inactivation by organic substances [1].

In the global dimension, a fairly large proportion of drugs for water disinfection, are made in tablet form. The practical advantages of these forms are precision of dosing, fast solubility, compactness, long-term storage (from 2 to 5 years).

For example, the tablets produced by "Kathadyn Group" (Switzerland) have two modifications: the first, simpler, include sodium dichloroisocyanurate (1\%) and sodium chloride (6.4\%) [2]; another modification contains Argentum chloride [3] and is announced as a disinfectant with prolonged action.

Regarding Ukrainian agents, it's worth to mention the "Sanidez" manufactured by "MDM" Ltd. in the form of tablets containing trichloroisocyanuric acid - 55\%; isocyanuric acid - 10\%, as well as auxiliary substances: sodium bicarbonate - 30\% and sodium carbonate - 5\% [4].

According to the standard documents on military hygiene, water disinfection in the field can be provided by neutral calcium or sodium hypochlorite and bleaching powder (ready-made solutions are used). In the absence of conditions for conducting analytical control, the method of water rehydration (addition of high content of chlorine), is used. If the water is relatively clean and does not have sources of pollution, a needed dose is $5 \mathrm{mg} / \mathrm{dm}^{3}$ of active chlorine. For turbid water, it is necessary to increase the dose of active chlorine to $10 \mathrm{mg} / \mathrm{dm}^{3}$, and for very polluted - up to 20 $\mathrm{mg} / \mathrm{dm}^{3}$. Dechlorination of water is carried out with sodium hyposulphite [5].

To disinfect water in flasks, it is recommended to use tablets with paradiglorsulfamidobenzoic acid related to a group of organic chloramines and characterized by high resistance in long-term storage [6]. One of the recommended agents is Pantocid, which is currently not available on the territory of Ukraine.

The action of chlorinated drugs occurs according to the staging mechanism.

1. Hydrolysis (for example, Sodium Dichloroisocyanurate):

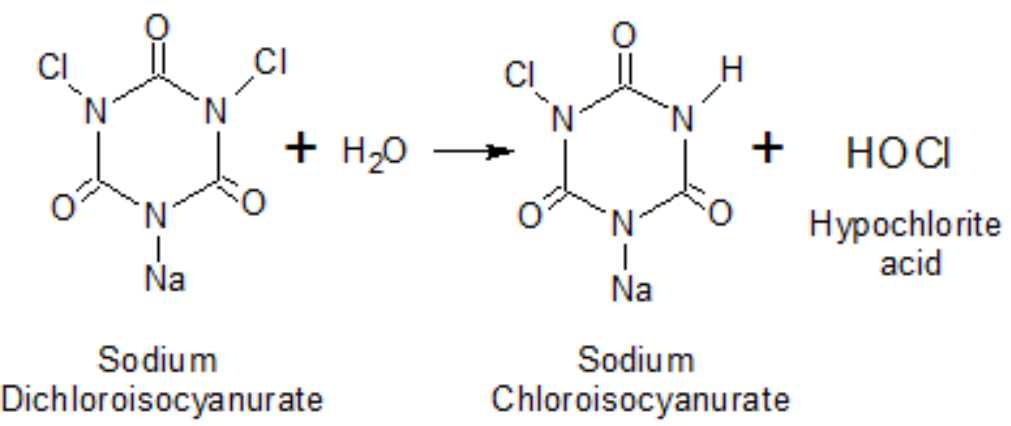

2. Dissociation of hypochlorite acid.

At $\mathrm{pH} \sim 7.0, \mathrm{HClO}$ dissociates: $\mathrm{HClO} \rightleftarrows \mathrm{H}^{+}+\mathrm{ClO}^{-}$.

3. Diffusion into the bacterial cell of the $\mathrm{HClO}$ molecule and of the $\mathrm{ClO}^{-}$ion.

4. Interaction of decontaminating agent with microorganisms enzymes, which are oxidized by chlorinated acid and hypochlorite ion.

At first, particles of active chlorine diffuse inside the bacterial cell, and then react with enzymes. The best bactericidal and virilidic action is provided by non-dissociated chlorinated acid $(\mathrm{HClO})$. The rate of water disinfection process is determined by the kinetics of chlorine diffusion inside the bacterial cell and the kinetics of dying out of cells as a result of metabolic disturbances. With increasing concentration of chlorine in water or its temperature, as well as the transition from chlorine to non-dissociated form, the overall rate of disinfection increases.

The mechanism of bactericidal action of chlorine consists in the oxidation of organic compounds of the bacterial cell: coagulation and damage to its shell, suppression, and denaturation of enzymes providing metabolism and energy. Thiol enzymes containing SH-groups, which are oxidized by chloric acid and hypochlorite ion, are most damaged. Among the thiol enzymes, in the 
first place, is a depressed group of dehydrogenases, which provide respiration and energy metabolism of the bacterial cell. Inhibition of dehydrogenase leads to inhibition of oxidation processes in the initial stages. The consequence of this is as the inhibition of the processes of bacterial reproduction (bacteriostatic action), and their destruction (bactericidal action).

The mechanism of action of active chlorine on the virus consists of two phases. Initially, adsorption of chlorinated acid and hypochlorite ion occurs on the shell of the virus and penetrates through it, and after- inactivation of the RNA or DNA of the virus.

As the $\mathrm{pH}$ value increases, the bactericidal effect of chlorine in water decreases. For example, in order to reduce the number of bacteria in water by $99 \%$ at a dose of free chlorine $0.1 \mathrm{mg} / \mathrm{dm}^{3}$, the contact time increases from 6 to 180 minutes at a pH increase of 6 to 11. Thus, it is recommended to disinfect water with chlorine at low $\mathrm{pH}$ values.

The presence in the water of organic compounds capable of oxidation, inorganic reducing agents, as well as colloidal and weighed substances that surround microorganisms, leads to slowing or stopping the process of disinfecting water [7].

Advantages of using chlorine-containing products are:

- the most effective agent;

- ease of dosing (especially in tablet form);

- investigated mechanisms of interaction and high efficiency with respect to a wide range of microorganisms;

- the convenient form of transportation.

Despite the widespread use of these agents, they have many disadvantages, namely:

- water disinfection makes it safe in relation to epidemiological factors, but does not remove from it the curds, heavy metals, etc.;

- in turbid water is not always sufficiently effective because of difficulties in dosing;

- products of the interaction of chlorine with organic compounds are toxic substances that adversely affect the human body.

\section{Iodine compounds}

According to the results of research [8], the iodization method is effective against bacteria and viruses and is not sufficiently effective, when exposed to microbial toxins and phenolic compounds. Another disadvantage of using iodine, in comparison with chlorination technologies, is the appearance of a specific taste of water. The advantages of water iodization before chlorination are that iodine is inert to ammonia and its derivatives, as well as have resistance to solar radiation.

The compounds of iodine in water are less hydrolyzed than chlorine compounds. The mechanism of their action is similar to chloro-compounds.

One example of iodine-based agents is Potable aqua pills. They contain tetraglycine hydroperiodide (16.7\%), which is equivalent to $6.68 \%$ of elemental iodine. The content of other substances in the agent is not disclosed [9].

The main advantages and disadvantages of using iodine-based disinfectants are similar to those of their chlorinated substitutes, but it should be noted that after treatment with such agents, the water has an unpleasant taste.

\section{Hydrogen peroxide}

Means based on hydrogen peroxide are rarely used in field water treatment technologies because this reagent is in a liquid form and difficult to dosage precisely. In developed countries, hydrogen peroxide is not positioned as a reagent for disinfecting water in the field.

"Sanoksil" is produced by DesoMark LLC (Ukraine) and contains hydrogen peroxide 48$52 \%$, Argentum nitrate $-0.075-0.085 \%$, phosphatic acid, and water. The duration of exposure to this reagent ranges from 15 to 120 minutes. The final concentration should be $1-5 \mathrm{mg} / \mathrm{dm}^{3}$. In the absence of such concentration in water, an additional dosage is required [10]. This mean is positioned by the manufacturer as such, that can be used in field conditions. The main disadvantage 
of using this agent and its analogs is the dosage of it in the limits when, in field conditions, the titrimetric determination of the reagent in water is objectively unrealized.

\section{Means based on polyhexamethylene guanidine ("Aquaton 10")}

"Aquaton 10" is produced in Ukraine by "Ukrvobsybka" PJSC. It contains 30\% polyhexamethylene guanidine hydrochloride (PGMG HC). The remedy is recommended for the disinfection of technological equipment for the preparation of drinking water and for the provision of epidemiologically safe water supply in emergency situations [11].

The main advantages of PGMG HC are a wide range of microbiological activity, low toxicity, complete solubility in water, biodegradability, as well as lack of color, odor, corrosion activity and storage stability.

Disadvantages of using the product in the field are the complexity of the expedient dosage and the determination of the final concentration of the active substance in the prepared water.

\section{Salt of silver as a water preservative}

Silver salts have long been known as having antibacterial properties. It is worth to mention that they have a bactericidal effect at a fairly small concentration in water (the smallest effective dose is $1-3 \mathrm{mg} / \mathrm{dm}^{3}$ ), but the duration of exposure is 3 hours [12]. Silver salts are effective against gram-negative (Escherichia, pseudomonads, salmonella, and vibrion) and gram-positive bacteria (Clostridium, Enterococcus, Listeria, Staphylococcus, Streptococcus and a wide range of rodshaped ones) [13].

The use of silver salts, as a separate disinfectant in the field, is unjustified because the time required to disinfect the water is quite long. Therefore, these compounds are often used as water preservatives and are included in preparations for the compounds based on chlorine and iodine.

The advantages of using silver salts as a component of combined means for disinfecting water in the field are:

- the possibility of reducing the concentration of the main active ingredient-oxidant;

- rather long-lasting decontamination effect compared with the use of excess concentrations of more toxic agents.

- the absence of toxic effects of small concentrations of silver on the human body based on the results of clinical trials [14].

One of the drawbacks is that silver requires a long exposure time and is a relatively expensive reagent.

\section{Disinfection with ultraviolet radiation}

Disinfection with ultraviolet irradiation in field conditions is used quite often. There are devices based both on sources of artificial ultraviolet radiation and on the effects of natural solar radiation.

The mechanism of action of UV rays is explained by photochemical reactions in the structure of DNA and RNA molecules, which constitute a universal information basis for the mechanism of reproduction of living organisms. The result of these reactions is irreversible damage to the structure of membranes and cell walls of microorganisms, which leads to their death [15].

The cheapest method of disinfecting water is the effect on it of solar radiation in transparent plastic containers. This technology was called "SoDis" (Solar water disinfection). The process is due to the heating and irradiation of water in a transparent polyethylene dish, which is displayed horizontally in a place exposed to solar radiation. At a high intensity of solar radiation, the holding time is 6 hours, in high clouds, the process takes about two days [16].

As an alternative to the classic method, the Swedish company "Solvatten" has developed a device for decontamination of water with sunlight. It consists of a $10 \mathrm{dm}^{3}$ black tank, which is laid out in the form of a book and has transparent plates that pases through the solar radiation inside. The advantage of this tool is the presence of a mechanical filter and black body, which improves the 
processes of absorption of UV and infrared rays, which significantly reduces the time of water treatment [17].

Exists a wide range of devices for disinfecting water treatment with artificial UV rays. Such devices are simple in design and consist of a UV lamp in a glass case, control unit, and battery.

As an example, it's fashionable to name the device "Steripen" produced by the company of the same name. It is positioned as a means of disinfecting relatively clean water and involves eight thousand cycles of water purification in a volume of $1 \mathrm{dm}^{3}, 100$ of them - on one set of batteries [18].

Among the advantages of water treatment methods, UV radiation should be highlighted:

- the simplicity of hardware design, small overall dimensions;

- an absence of contaminated by-products;

- process speed (about $90 \mathrm{sec}$ );

- low cost.

The disadvantages include:

- inefficiency in most of the toxic compounds, including heavy metals;

- mandatory supply of a power source (battery or battery), which is not always convenient in the field;

- low efficiency for turbid water;

- an absence of prolonged action.

\section{Group water treatment plants}

The first water treatment plants in the field appeared before the Second World War. In 50 years of XX century technologies divided into three main types: seawater desalination plants, facilities for the disposal of radioactive, biological and chemical contaminants and installations for purifying relatively clean water.

There are many design solutions of group drinking water plants in the field, but, in general, almost all known examples include phase specific for standard technological schemes of water purification, namely:

- mechanical filtration through sieves and nets;

- mechanical filtering through filters with filling and/or polypropylene, tissue cartridges or bag filters;

- the stage of softening by ion exchange is not always present, but in most cases;

- adsorption on activated carbon;

- membrane technology;

- disinfection.

International Corporation "Aspen" (USA) has developed plants for desalination sea water and fresh water purifying. It has capacity from $2.6 \mathrm{dm}^{3}$ to $2 \mathrm{~m}^{3}$ per minute and used by the US combats, emergency services, and the border guards. The easiest installation of freshwater cleaning "Aspen 1800BC" weighs about 30 kilograms and has additional equipment and spare parts weighing about $23 \mathrm{~kg}$. It is designed as two padded backpacks (own installation and additional equipment).

As with other technologies for cleaning the fresh water of this corporation, the installation is based on several technological processes, namely:

- mechanical filtering (on the first stage are removed large particles of dirt with the mesh filter, the second - suspended particles and pathogens up to 1 micron). In modifications of greater productivity there are more stages of mechanical filtering to reduce the load on each individual filter;

- removal of heavy metals and organic contaminants (an exchangeable cartridge is installed, the filling composition of which is not disclosed by the manufacturer);

- ultraviolet disinfection and post-chlorination [19].

This and other installations are also equipped with monitoring and control tools, batteries and/or autonomous power supply can be disabled in case of equipment failure. 
According to similar schemes, the plants of the international corporation "Meco" and others are working. Little differences have filters manufactured by the Swiss company "Katadyn". The main structural element of these systems is ceramic microfilters.

Depending on the tasks, the performance and processes, and, accordingly, the components of the installations are changing. The main differences between "field" and stationary installations are given in Table 1.

Table 1. Characteristic features of stationary and "field" installations for the drinking water preparation

\begin{tabular}{|c|c|c|}
\hline $\begin{array}{c}\text { Characteris } \\
\text { tic features }\end{array}$ & Stationary plants & Field installation \\
\hline $\begin{array}{c}\text { Power } \\
\text { supply source }\end{array}$ & $\begin{array}{c}\text { Centralized (power } \\
\text { supply from the network) }\end{array}$ & $\begin{array}{c}\text { Independent(Accumulators, } \\
\text { electric generators) }\end{array}$ \\
\hline Initial & $\begin{array}{c}\text { Has a stable chemical } \\
\text { composition }\end{array}$ & $\begin{array}{c}\text { It is difficult to predict the } \\
\text { composition and physical parameters } \\
\text { of feeding water }\end{array}$ \\
\hline Location & $\begin{array}{c}\text { Stationary conditions, } \\
\text { very low mobility }\end{array}$ & $\begin{array}{c}\text { Highly mobile (a backpack, a } \\
\text { bag, large installations on the basis of a } \\
\text { car/car or easy to install) }\end{array}$ \\
\hline Service & $\begin{array}{c}\text { There is always a need } \\
\text { for qualified staff }\end{array}$ & $\begin{array}{c}\text { Maximally easy to use, the } \\
\text { interface is available to an uneducated } \\
\text { user }\end{array}$ \\
\hline $\begin{array}{c}\text { Analytical } \\
\text { control }\end{array}$ & $\begin{array}{c}\text { Present at all levels } \\
\text { preservation of membrane } \\
\text { elements is required } \\
\text { absence of loading, }\end{array}$ & $\begin{array}{l}\text { Minimized to elementary } \\
\text { operations. Test strips and droplets are } \\
\text { often used }\end{array}$ \\
\hline Equipment & $\begin{array}{l}\text { Cartridge filters, minimized } \\
\text { flushing processes, membrane }\end{array}$ \\
\hline
\end{tabular}

The benefits of group drinking water provision are:

- the high quality of purified water;

- the possibility of analytical control.

The disadvantages of group installations are fashionable:

- can not provide the potable water of individuals who are away from the places of the disposition of the main part of the personnel of units or groups of people.

- usually have a certain level of noise, which limits the combat use in situations where it can be a factor in the disclosure of the position.

- carry an environmental hazard in the form of non-regenerated filtering elements that are emitted into the garbage.

\section{Individual technologies}

Today, there are a large number of "pocket" filters for water purification in the field, most of them are completely autonomous, do not need an energy source and provide a high level of drinking water quality.

The effect of most existing devices is based on the application of membrane processes based on polymeric and ceramic microfiltration membranes made by different technologies. The use of 
microfiltration processes is due to the low-pressure drop on this type of membrane, and the lightness and small size of the elements give them an advantage over cartridges with fillings. The only disadvantage of using microfiltration membranes is that they can pass viruses, so some devices provided disinfection with iodine or other oxidizing biocide agents and which are, in most cases, trade secret.

Most gadgets also include mechanical filters in the form of polymer or metal nets, carbon adsorption elements in the form of filling cartridges or sintered carbon blocks.

In the devices under consideration, there is no signaling about the exhaustion of the filter resource due to the technological complexity of this process.

Below are shown examples of devices that reflect the basic principles of the work of the individual water treatment technologies that are currently used in the world.

\section{"Lifestraw" technology}

The "Lifestraw" technology was first developed in 2005 for use in disasters and is currently used as a mean of purifying water, both in regions where there is a critical shortage of clean water and in conditions, that are created in tourist trips.

The device consists of plastic or metal enclosures, prefilter grids, activated carbon and membrane modules. The efficiency of the filter reaches $1000 \mathrm{dm}^{3}$, which is enough to provide clean water for one person during the year [20].

The studies conducted in 2010-2015 confirmed the removal of bacteria (Brucella melitensis, Campylobacter tularensis, Pasteurella aeruginosa, Pseudomonas, Shigella, Aureus Staphylococcus, Cholera Vibrio, parahaemolyticus Vibrio, Enterocolitica Yersinia, pestis Yersinia, coli.E, Enteropathogenic, influenzae Haemophilus, pneumoniae Klebsielia, pneumophia Legionella, Tuberculosis Mycobacterium, pneumoniae Mycoplasma, pseudomallei Pseudomonas, hirschefeldii Salmonella, typhimurium Salmonella, typhosa Salmonella, dysenteriae Shigella, pneumoniae Streptococcus, pyogenes Streptococcus) to $99.9999 \%$ as well as $99.9 \%$ parasite removal ( ascarids, cryptospridium, libblichhardias, schistos, etc.). The more complex modifications of the device are also effective against viruses [21], due to the decontamination stage, but provide for the provision of water by a group of people and need additional storage capacity for the storage of purified or offwater.

The work of the gadget is based on the use of a cartridge membrane element with a hollow fiber structure, which explains the high level of water purification.

\section{Katadyn Technologies}

"Katadyn Group" is a Swiss company whose job is to provide people with drinking water and food in the field, including emergencies and hostilities.

The products of the company are disinfecting tablets and devices, as well as universal filters for water. They include a number of devices designed for personal use. The most widespread were [22]:

- "KATADYN HIKER PRO" consists of a mechanical inlet filter, a ceramic prefilter, a glass fiber cartridge and an activated carbon cartridge.

- "KATADYN VARIO" consists of a mechanical inlet filter, a ceramic prefilter, a glass fiber cartridge and an activated carbon cartridge.

- "KATADYN POCKET" consists of a mechanical filter mesh and a ceramic filter with a filtering rating of 0.2 microns [23].

All these filters remove bacteria, protozoa, cysts, algae, spores and dissolved particles. These devices are ergonomic and provide safe and high-quality water. Distributed in the work of charitable organizations, military formations, as well as for tourist purposes. 


\section{Nerox Filters}

The production of these filters began more than twenty years ago by the company NPP "Simpex" (Ukraine). The main structural element of this filter is the track membrane, invented by the Joint Institute for Nuclear Research (Dubno, Russia).

According to studies [24], these membranes have high efficacy against microbiological contaminants and heavy metals.

The track membrane is made of polymeric (lavsan) films thickness 10-23 microns by bombarding their high-energy krypton ions, penetrating the film through. In the passage of individual ions channels of destroyed material (tracks), differing in their physical and chemical properties from undamaged ions of the material, are formed. With further etching, the film treated with ions in the alkaline solutions at the site of the tracks creates exactly the same through holes of a cylindrical shape. The diameter of these openings may range from 0.05 to 3 microns, depending on the conditions of etching.

For the mass production of track membranes, a U-400 ion accelerator is used, which produces up to 1012 ions per second for the nuclear reactions of the JNII, and allows to receive track membranes with a pore density in the range 105-109 pores per $1 \mathrm{~cm}^{2}$. The porosity of such membranes is $10-15 \%$. The main property of track membranes, that distinguishes them from other types of membranes, is their high selectivity (all single pores have the same diameter with deviations of no more than 5\%) [25].

Advantages of individual means of purifying drinking water in the field:

- complete autonomy of a person relative to the source of water supply;

- ease of operation;

- absence of additional products of disinfection reactions.

The disadvantages include:

- Inefficiency in viruses, heavy metals, and some organic compounds;

- absence of a mechanism for monitoring water quality and filter status.

\section{Ukrainian experience in water preparation in the field}

The question of combat drinking water supply was a hot topic in the summer of 2014 in the East of Ukraine when it turned out that the traditional methods proposed by the instructions are complicated to implement, require skilled personnel or are generally obsolete.

Today, in Ukraine, there are a number of technological solutions to water supply problems in the field. Below are shown the main ones.

All these technologies are aimed to provide drinking water for human groups of 4-5 people and teams of 1,000-1,500 people, which is mainly due to the economic feasibility of creating very large-scale installations. There are no individual water purification facilities of domestic development.

\section{Portable water treatment plant "Owl"}

The plant clears contaminated or potentially dangerous water from microorganisms, pesticides, heavy metals and other hazardous impurities. The productivity of the installation - 30 $\mathrm{dm}^{3} / \mathrm{h}$. Resource - more than 500 liters of purified water on one set of cartridges. Does not require a source of power or other sources of energy - the installation is powered by muscular power (completely autonomous). The process of water purification includes the following stages: decontamination and removal of suspended impurities; removal of soluble organic impurities; fine mechanical finishing.

All components and consumables are made in Ukraine. The technology used in the installation is well-scaled - with its use, more power plants can be developed to provide drinking water for large groups of people - in the conditions of ATOs or emergencies, for small settlements, 
etc. The installation was developed in the laboratory of environmental technologies NTUU "KPI" under the auspices of the Science Park "Kyiv Polytechnic" [26].

The technology is based on a biocidal polymer of complex action (polyhexamethylene guanidine hydrochloride PGMG HC), which combines the properties of disinfectant, flocculant and the complexing agent.

PGMG HC has bactericidal properties related to gram-negative and gram-positive bacteria (including Mycobacterium tuberculosis), virilidic agents (including AIDS/HIV, hepatitis, poliomyelitis, influenza viruses, etc.), fungicides (including pathogens, candidiasis, dermatophytes, etc.) and algicidal properties [27].

One of the main advantages of using PHMG HC is its virucidal action, due to which the installation is more versatile than most analogs using membrane technologies.

\section{Household filter for water treatment with variable load}

This tool is not serially manufactured, but there are several experimental designs.

The filter is designed to remove iron, to increase the safety of purified water as a result of the destruction of pathogenic viruses and coliform bacteria, coliphages, Clostridium spores, lamblia cysts, as well as the removal of toxic compounds that are found in contaminated water and are formed during its treatment.

The process of water treatment includes the steps:

- disinfection (chlorination);

- excerpts;

- separation of sediment;

- filtration;

- dechlorination.

Advantages of the device: easy to use in all conditions without excessive pressure and electricity; easy replacement of the load and, if necessary, the simple introduction of the disinfectant component in the form of tablets.

The filter consists of any tare of a food purpose, which has a corresponding opening for the disconnecting of the enclosure, which holds the filter-sorption material. The filtration is performed under pressure of the water column, the filtration rate is controlled by the output valve.

Depending on the indicators of water purity, as a sorption-filter material, activated charcoal of various porous structures is usually used to remove soluble organic pollutants, chemicals, petroleum products, chlorinated derivatives, etc. [28].

\section{Water treatment plant "Oasis"}

The first development, aimed at providing drinking water to the Ukrainian military and civilians in the area of the anti-terrorist operation, was the mobile plant "Oasis" produced by the "EkoSoft" NPO. The installation has proven itself well and today it is on a free sale.

The plant's productivity is about $300 \mathrm{dm}^{3} / \mathrm{h}$, and the capacity for flushing is $34 \mathrm{~m}^{3}$ of water.

The basis of the mobile installation is the classical technology, which is foreseen by the normative documents, regarding the purification of fresh water in natural waters. The technology involves the obligatory disinfection of a chlorinated agent. If necessary, coagulants and flocculants can be added to the water. Then the water is settled and consistently fed into grain-loaded and activated carbon filters. Before serving, water passes through the stage of microfiltration and the stage of finishing chlorination [29].

The main advantages of the installation that it is easy to maintain and repair, is mobile and resistant to the environmental conditions, does not contain expensive items of construction, which causes the relatively low cost of the installation itself.

The disadvantages are the impossibility of removing heavy metal salts, the lack of simple analytical control mechanisms and the use of water for the needs of the installation. 


\title{
Conclusions
}

As a result of the investigated sources, information on the domestic and international experience of water preparation in the field was systematized. Below is a number of conclusions.

Disinfection of water makes it safe from microbiological hazards but does not remove other impurities that may have high toxicity.

Individual water treatment solutions are more expensive, but have a long service life, are easier to use and do not require complicated maintenance. Technologies aimed to provide water for large groups of people are always simpler, cheaper and in most cases include traditional methods of water treatment. The main advantage of individual technologies is the complete autonomy of the device and, accordingly, the person who uses it.

Plants designed to provide water to groups of people require more technological equipment, have a larger size and require to be serviced by skilled personnel. The main advantage of group installations is the relatively low cost of water, compared with individual methods.

The situation with the preparation of water in the field in Ukraine remains tense, because, despite the existing developments, none of them has received widespread dissemination. There are no individual technologies for water purification of domestic development.

\section{ОГЛЯД АКТУАЛЬНИХ МЕТОДІВ І ТЕХНОЛОГІЙ ОБРОБКИ ВОДИ У ПОЛЬОВИХ УМОВАХ (огляд літератури)}

\author{
А.В Кузьмінчук, І.М. Астрелін \\ Національний технічний університет України "Київський політехнічний інститут імені \\ Ігоря Сікорського", м.Київ
}

Огляд присвячений проблемі підготовки води у польових умовах. Приводиться перелік та опис сучасних методів підготовки питної води у польових умовах. Розглянуто засоби та установки, щуо мають в основі прочеси знезараження, механічного фільтрування, знесолення, адсорбиії, мембранного розділення та їх комбіначіï. Вивчено та детально описано існуючі в Україні $і$ світі засоби (таблетки, розчини) та пристрої (УФвипромінювачі) дезінфекції води, індивідуальні фільтрувальні пристрої та групові установки підготовки питної води.

Найпотиренішим сьогодні методом підготовки води $\epsilon$ ї̈ знезараження. Детально описано таблетовані засоби на основі похідних сполук хлору (солі хлорізоціанурової кислоти,Пантоцид) та йоду (переважно тетраглічиин гідроперійодид), щзо $\epsilon$ найпопулярнішими знезаражуючими реагентами у польових умовах. Розглянуто менш зручні у використанні та не менш ефективні рідкі знезаражуючі засоби на основі пероксиду водню та полігексаметилгуанідину гідрохлориду. Ще одним иляхом знезараження води $\epsilon$ використання пристроїв на базі ультрафіолетового випромінювання. Головною перевагою усіх знезаражувальних технологій є їх швидкість, простота і дешевизна. Щодо недоліків, варто згадати те, щзо процеси дезінфекиії не забезпечують видалення часток забруднень, а лиме частково руйнують їх, більшість деззасобів залишають по собі негативний присмак, а пристрої з УФ-лампою не дають пролонгованого ефекту.

Що стосується групових установок підготовки питної води, сучасний ринок пропонує широкий ряд таких пристроїв різної продуктивності. Принщип їх дії зазвичай базується на прочесах, характерних для стаціонарних установок водоочищення, а саме механічного фільтрування, пом'якшення, адсорбиії, мембранних технологій та знезараження. Групові 
технології беззаперечно є найефективнішим методом підготовки питної води у польових умовах, але висока вартість обладнання стримує їх широке розповсюдження.

Індивідуальні технології підготовки питної води передбачають наявність “кишенькогово” пристрою, головним елементом якого у існуючих сьогодні зразках $\epsilon$ мікрофільтраційна мемрана. Засоби зручні у використанні, відносно недорогі, але не забезпечують повного видалення токсичних забруднень.

Вітчизняний ринок “польових" пристроїв підготовки води почав активно розвиватися у 2014 році. У статті розглянуто існуючі пристрої украӥнського виробництва, а саме переносну установку для очистки води “Сова" та установку очщщення води “Оазис".

Ключові слова: питна вода, польові умови, мікрофільтрація, хлорні таблетки.

\title{
ОБЗОР МЕТОДОВ И ТЕХНОЛОГИЙ ОБРАБОТКИ ВОДЫ В ПОЛЕВЫХ УСЛОВИЯХ (Обзор литературы)
}

\author{
А.В Кузьминчук, И.М. Астрелин \\ Национальный технический университет Украины "Киевский политехнический \\ институт имени Игоря Сикорского", г. Киев
}

Данный обзор посвящен проблеме подготовки воды в полевых условиях. Приводится перечень и описание методов подготовки питьевой воды в полевых условиях, а именно прочессы обеззараживания, механической фильтраџии, обессоливания, адсорбиии $u$ мембранного разделения. Рассмотрень существующие в Украине и мире средства (таблетки, растворы) и устройства (УФ-излучатели) дезинфекиии воды, индивидуальные фильтровальные устройства и групповые установки подготовки питьевой водь. Проведен критический анализ преимуществ и недостатков всех рассмотренных технологий. таблетки.

Ключевые слова: питьевая вода, полевые условия, микрофильтрачия, хлорные

\section{REFERENCES}

1. Shevcov A.B, Kozyreva A.V., Aedunov S.G., Chlorine disinfectants and their use in modern water treatment. . Molekulyarnye tekhnologii. 2009, 3. 214.

2. MICROPUR MP1 PURIFICATION TABLETS, available at: https://www.katadyn.com/us/us/403-8014996-micropur-mp1-20-usa-only.

3. MICROPUR FORTE MF 1T DCCNA, available at: https://www.katadyn.com/en/ch/119$\underline{\text { 8014258-micropur-forte-mf-1t-dccna-de-e-f-nl-it }}$

4. Sanidez. Zasib dezinfektsiyniy khlorniy [Sanedes. Chlorine disinfectant] available at: http://mdmgroup.com.ua/wp-content/uploads/2015/12/Sanides.pdf. [in Ukrainian].

5. Pashko K.O. Military emergency hygiene. (Ternopil: Ukrmedknyha, 2005). [in Ukrainian].

6. Water purification in field http://profmed.at.ua/index/ochishhennja_ta_znezarazhuvannja_vodi_v_polovikh_umovakh/ 0-233. [in Ukrainian].

7. Ye. I. Honcharuk, V. H. Bordov, S. I. Harkavyi. Communal hygiene. Educational publications. (Kyiv: Zdorovia, 2006). [In Ukrainian].

8. Khokhriakova E. Modern methods of water disinfection. (Moskow: Izdatelskyi Tsentr «Akva-Term», 2014). [In Russian].

9. Potable aqua. Active ingridients. - available at: http://www.potableaqua.com/wpcontent/uploads/2014/10/IngredientsPotableAqua.pdf. 
10. Methodical instructions on the use of "Sanocyl 100". (Kyiv, Ukraina.: Derzhavna sanitarnoepidemiolohichna sluzhba Ukrainy, 2014). [in Ukrainian].

11. Instruction on the application of a disinfectant "Complex action reagent" Aquaton-10 "produced by PJSC" STC "UKRVODBEZPEKA" (Ukraine) for disinfection of water and water treatment facilities with decentralized and autonomous water supply. (Kyiv, 2013). [in Ukrainian].

12. Kulman A. H. General chemistry. (Moskow: Kolos,1968). [in Russian].

13. Dr Lorna Fewtrell. Silver: water disinfection and toxicity. (Spring, Utah, USA: Centre for Research into Environment and Health, 2014)

14. Munger M.A., RadNanomedicine. 2014wanski P., Hadlock G.C., Stoddard G., Shaaban A., Falconer J., Grainger DW., Deering-Rice C.E. In vivo human time-exposure study of orally dosed commercial silver nanoparticles. Nanomedicine. 2014. 10 (1): 1. doi: 10.1016/j.nano.2013.06.010.

15. Khokhriakova E.A., Reznyk Ya. E., S.E. Belykov (2007) Vodopodhotovka: Spravochnyk. [Water treatment. Handbook]. S.E. Belykov(Ed.). Moskow: Yzdatelskyi Tsentr «AkvaTerm» [In Russian]

16. SoDiS. Safe drinking water for all. 2011. - available at: http://www.sodis.ch/methode/index_EN.

17. Goodier R. A solar water sterilizer takes aim at rural African markets. USA: Engineering for change. 2011. - available at: https://www.engineeringforchange.org/news/a-solar-watersterilizer-takes-aim-at-rural-african-markets/.

18. Timmermann L.F., Ritter K., Hillebrandt D., Küpper, T. Drinking water treatment with ultraviolet light for travelers-Evaluation of a mobile lightweight system. Travel medicine and infectious disease. 2015. 13 (6): 466. https://doi.org/10.1016/j.tmaid.2015.10.005

19. ASPEN 1800BC DESIGN CRITERIA - available at: http://www.aspenwater.com/documents/1800designcriteria.pdf

20. Life Straw. We make contaminated water safe to drink. - available at: http://www.lifestraw.com/.

21. Evaluation of Vestergard-Frandsen's hollow fiber LifeStraw for the removal of Escherichia Coli and Criptosporidium according to the U.S. enviromental protection agency guide standart and protocol for evaluation of microbiological water purifiers. (Tucson, Arizona: Department of Soil, Water and Enviromental Science. College of Agriculture and Life Sciences. the University of Arizona, 2010).

22. The pros and cons of the most common water Preparation Systems. (Kemptthal, Switzerland: Katadyn group).

23. Katadyn group. Water treatment - available at: https://www.katadynmilitary.com/us/us/products/water-treatment.

24. Antypova A. V. Nerox. High technology and reasonable efficiency. Voda i vodoochysni technologii. 2007. 2. 68 [In Russian]

25. Track Membrane. Unique filtration material. Voda i vodoochysni technologii. 2008. 2. 73 [In Russian]

26. Portable installation "Sova" cleans water. Kyiv: Kyivskyi Politecnik. 2015. 6. 3. [In Ukrainian].

27. Instructions for using disinfectant "Complex action reagent" Aquaton-10 "produced by PJSC STC" UKRVODBEZPEKA "(Ukraine) for disinfection of water and water treatment facilities with decentralized and autonomous water supply. Kyiv. 2013. [In Ukrainian]

28. Patent UA 90139 U. Ponomarov V. L., Isakov A. A. Steering device for water purifying and iron removal with a variable filling. 2013.

29. V. L. Ponomarov. The source of drinking water in emergency situations. Kiev:WaterNet. [in ukrainian]- available at: http://waternet.ua/uk/news/newsletter/166/. 